\title{
The value and generalizability of cost-effectiveness research
}

\author{
John F. Butterworth IV, MD, ${ }^{a}$ and Anthony D. Cassano, MD, MSHA ${ }^{b}$ \\ From the ${ }^{\mathrm{a} D e p a r t m e n t}$ of Anesthesiology and ${ }^{\mathrm{b}}$ Division of Cardiac and Thoracic Surgery, Department of Surgery, \\ Virginia Commonwealth University School of Medicine, Richmond, Va. \\ Disclosures: Authors have nothing to disclose with regard to commercial support. \\ Received for publication Dec 2, 2017; accepted for publication Dec 18, 2017; available ahead of print Feb 1, 2018. \\ Address for reprints: John F. Butterworth IV, MD, Department of Anesthesiology, Virginia Commonwealth Uni- \\ versity School of Medicine, PO Box 980695, Richmond, VA 23298-0068 (E-mail: jfbivjbutter@yahoo.com). \\ J Thorac Cardiovasc Surg 2018;155:1684-5 \\ $0022-5223 / \$ 36.00$ \\ Copyright (c) 2017 by The American Association for Thoracic Surgery \\ https://doi.org/10.1016/j.jtcvs.2017.12.064
}

Insurers, regulators, and clinicians use cost-effectiveness analyses (CEAs) in the hope of defining those drugs and forms of care that make the best use of our limited resources. Thus, it is very appropriate that Ferket and colleagues ${ }^{1}$ provide a primer on these techniques in this issue of the Journal.

Some judgments regarding cost-effectiveness seem obvious. Drug treatment of essential hypertension avoids the complications of heart, kidney failure, or stroke and is inexpensive, efficacious, and cost-effective. ${ }^{2}$ Similarly, drug treatment of chronic heart failure with angiotensinconverting enzyme inhibitors easily meets our tests for cost-effectiveness. ${ }^{3}$

The decision-making is not always so clear cut when costs of supplies, personnel, hospitalizations, and complications must be estimated. ${ }^{1}$ Outcome differences associated with medications can usually be attributed to the medication, not the clinician; however, surgeons have varying skills and experiences. Can one reasonably compare either the cost or the effectiveness of robot-assisted laparoscopic radical prostatectomy with "open" retropubic prostatectomy without regard for the operator's expertise? $?^{4,5}$

These concerns are even more vexing in cardiovascular and thoracic surgery. When we compare off-pump with on-pump coronary artery bypass grafting, are we actually comparing the same revascularization ${ }^{6}$ What is the effectiveness outcome of interest? Mortality at 1, 3, or 5 years? Graft patency? Incidence of a combined endpoint? ${ }^{7}$ Would our 50-year-old patient who enjoys mountain biking regard percutaneous coronary intervention, with a requirement for daily antiplatelet therapy, as more cost-effective than coronary artery bypass grafting when the former is associated with an increased risk of intracranial bleeding or death should he fall during a ride? ${ }^{8-10}$

Fundamentally, CEA seeks "fairness," and we certainly support this aim. In contrast, we wonder whether it makes sense to assume that all patients would place the same dollar value on a quality-adjusted life year in a country with no "single payer" and in which "concierge" medical services are proliferating. Would all patients agree with our cost

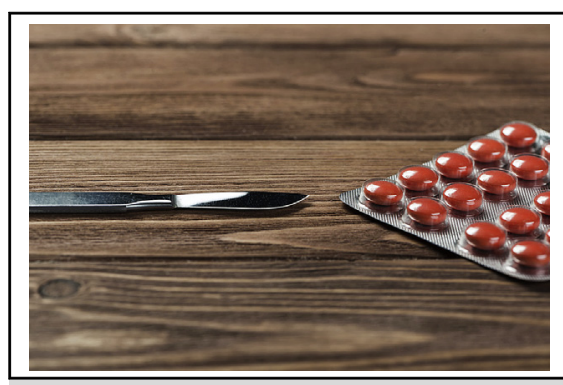

Cost-effectiveness analysis is far less straightforward for surgical than medical therapy. Copyright: https:// www.123rf.com/profile_adam121.

Central Message

Cost-effectiveness analyses should be performed and interpreted carefully and cautiously because they may be used to dictate the procedures and treatments we can offer our patients.

See Article page 1671.

estimate of a periprocedural stroke? Would they agree with our estimate of the financial benefit from avoiding blood transfusion or an extra day of hospitalization? Unfortunately, the marked variation in costs of care within the United States and the marked differences in costs of supplies and services in the United States versus other countries ultimately make CEAs less generalizable than would be desired. $^{11-13}$

Another limitation is that source data for CEA are typically "mined" from national databases. These sources provide data of varying quality and validity and usually lack the clinical information that actually drives decisions regarding which medical procedure will be performed. CEA needs to address clinical decision-making, patient outcomes, and satisfaction data. A primary focus on costs may benefit our bottom line but may be detrimental to our patients. CEA does not produce a static number: we must be prepared to redo our calculations when the relative costs of a treatment changes radically (eg, when the patent life of a drug or robot expires and market competition drives down costs).

CEA analyses should be performed carefully and cautiously because they may be used by third-party payers to dictate the procedures and treatments we can offer our patients. CEA is an important field of study, and our readers must be prepared to address these issues as they arise in their health systems. Thus, we welcome the contribution of Ferket and colleagues to the Journal. ${ }^{1}$ 


\section{References}

1. Ferket BS, Oxman JM, Iribarne A, Gelijns AC, Moskowitz AJ. Cost-effectiveness analysis in cardiac surgery: a review of its concepts and methodologies. $J$ Thor Cardiovasc Surg. 2018;155:1671-81.

2. Reboussin DM, Allen NB, Griswold ME, Guallar E, Hong Y, Lackland DT, et al. Systematic review for the 2017 ACC/AHA/AAPA/ABC/ACPM/AGS/APhA/ ASH/ASPC/NMA/PCNA guideline for the prevention, detection, evaluation, and management of high blood pressure in adults: a report of the American College of Cardiology/American Heart Association task force on clinical practice guidelines. Hypertension. November 13, 2017 [Epub ahead of print].

3. Biglane JB, Becnel MF, Ventura HO, Krim SR. Pharmacologic therapy for heart failure with reduced ejection fraction: closing the gap between clinical guidelines and practice. Prog Cardiovasc Dis. 2017;60:187-97.

4. Ilic D, Evans SM, Allan CA, Jung JH, Murphy D, Frydenberg M. Laparoscopic and robot-assisted vs open radical prostatectomy for the treatment of localized prostate cancer: a Cochrane systematic review. BJU Int. October 24, 2017 [Epub ahead of print].

5. Leow JJ, Leong EK, Serrell EC, Chang SL, Gruen RL, Png KS, et al. Systematic review of the volume-outcome relationship for radical prostatectomy. Eur Urol Focus. April 6, 2017 [Epub ahead of print].

6. Puskas JD, Williams WH, Mahoney EM, Huber PR, Block PC, Duke PG, et al. Offpump vs conventional coronary artery bypass grafting: early and 1-year graft patency, cost, and quality-of-life outcomes: a randomized trial. JAMA. 2004;291:1841-9.

7. Kirmani BH, Holmes MV, Muir AD. Long-term survival and freedom from reintervention after off-pump coronary artery bypass grafting: a propensity-matched study. Circulation. 2016;134:1209-20.

8. Mäkikallio T, Holm NR, Lindsay M, Spence MS, Erglis A, Menown IB, et al; NOBLE study investigators. Percutaneous coronary angioplasty versus coronary artery bypass grafting in treatment of unprotected left main stenosis (NOBLE): a prospective, randomised, open-label, non-inferiority trial. Lancet. 2016;388: 2743-52.

9. Stone GW, Sabik JF, Serruys PW, Simonton CA, Généreux P, Puskas J, et al: EXCEL Trial Investigators. Everolimus-eluting stents or bypass surgery for left main coronary artery disease. $N$ Engl J Med. 2016;375:2223-35.

10. Poder TG, Erraji J, Coulibaly LP, Koffi K. Percutaneous coronary intervention with second-generation drug-eluting stent versus bare-metal stent: systematic review and cost-benefit analysis. PLoS One. 2017;12:e177476.

11. Wakeam E, Molina G, Shah N, Lipsitz SR, Chang DC, Gawande AA, et al. Variation in the cost of 5 common operations in the United States. Surgery. 2017;162: 592-604.

12. Guduguntla V, Syrjamaki JD, Ellimoottil C, Miller DC, Prager RL, Norton EC, et al. Drivers of payment variation in 90-day coronary artery bypass grafting episodes. JAMA Surg. August 23, 2017 [Epub ahead of print].

13. Silva GSD, Colósimo FC, Sousa AG, Piotto RF, Castilho V. Coronary artery bypass graft surgery cost coverage by the Brazilian Unified Health System (SUS). Braz J Cardiovasc Surg. 2017;32:253-9. 